\title{
Abundance and Distribution of Odonates (Dragonflies and Damselflies) In Akwa Ibom State, Nigeria
}

\author{
Kehinde A. Kemabonta ${ }^{1 *}$, Rosemary Essien ${ }^{2}$, Babasola W. Adu ${ }^{3}$, Sylvester U. Ogbogu ${ }^{4}$, \\ Abdussalam Iysa ${ }^{1}$, Rhema Uche-Dike ${ }^{1}$ \\ ${ }^{1}$ Department of Zoology, University of Lagos, Akoka Lagos State, Nigeria \\ ${ }^{2}$ Department of Crop Protection, Akwa Ibom State University, Uyo, Akwa Ibom State, Nigeria \\ ${ }^{3}$ Department of Biology, Federal University of Technology, Akure, Ondo State, Nigeria \\ ${ }^{4}$ Department of Zoology, Obafemi Awolowo University, Ile-Ife Osun State Nigeria. \\ ${ }^{*}$ Correspondence should be addressed to Kehinde A. Kemabonta; kkemabonta@unilag.edu.ng \\ Received 21st December 2018; Revised 13th January 2019; Accepted 16th January 2019 \\ (C) 2019 Kemabonta et al. Licensee Pan African Journal of Life Sciences. This is an Open Access article distributed under the \\ terms of the Creative commons Attribution License (https://creativecommons.org/licenses/BY/4.0), which permits unrestrict- \\ ed use, distribution, and reproduction in any medium, provided the original work is properly cited.
}

\begin{abstract}
Introduction: Odonates are used as bio-indicators for monitoring habitat degradation both on terrestrial and aquatic ecosystem because of their sensitivity to anthropogenic activities. They serve an important role in the ecological food chain by consuming aquatic larvae and being in turn consumed by birds and various amphibians. This study is part of the ongoing research on the diversity of Odonate species of Nigeria. The objective is to determine the abundance and distribution of odonates in Akwa Ibom State and to compare the species diversity across the various sites in Akwa Ibom State.

Methodology: Akwa Ibom state was divided into six areas namely Ikot Akpaden, Obio Akpa, Ikot Okoro, Ikot Udofia, Urua Udofia and Obio Ndot using biotypes and a study site was randomly selected in each area. Adult members were captured using a sweep net and were preserved for identification using morphological features.

Results: A total of 767 odonates were collected at the six study sites representing 24 species, 16 genera and four families namely Libellulidae (77\%), Coenagrionidae (21\%), Calopterygidae (>1\%) and Chlorocyphidae ( $>1 \%)$. Most of the species collected were members of family Libellullidae (77\%) with Palpopleura lucia having the highest occurrence (41\%) and found in all the sites. Family Calopterygidae and Chlorocyphidae had less than $1 \%$ population of the total individuals collected. Ikot Okoro had the highest number of individuals (238) and the least evenness $\left(\mathrm{e}^{\wedge} \mathrm{H} / \mathrm{S}=0.3292\right)$ while Ikot Akpaden, which had the least effect of anthropogenic intrusion had the largest diversity of Odonata species $\left(\mathrm{H}^{\prime}=2.387\right)$. Obio Ndot had the most evenly distributed Odonata species $\left(\mathrm{e}^{\wedge} \mathrm{H} / \mathrm{S}=\mathrm{0.8028}\right)$. There was no statistical difference in the occurrence of dragonflies across all study sites $(\mathrm{p}=0.238)$.

Conclusion: The high occurrence of family Libellulidae which are anthropogenic tolerant, and the absence of more highly localized species indicate that most of the study sites have been degraded and may not be fit for species with narrow niches. It is therefore vital to conserve the Odonata community by implementing proper forest management techniques.
\end{abstract}

Keywords: Odonata, Libellulidae, Coenagrionidae, Calopterygidae, Chlorocyphidae, diversity 


\section{1.o INTRODUCTION}

Order Odonata consists of attractive and interesting members of the freshwater community. Most species have eye-catching markings and are among the most beautiful of insects [1]. Some species are strong flyers, and their adults can be found far from water. Others are typically found only near the edge of the water bodies in which the larvae develop [1]. The order is highly diverse with about 6,500 species [2]. All known species of Odonata are predators as adults and larvae. Dragonflies are mostly generalists that feed on whatever suitable prey is abundant. Diptera, especially mosquitoes and midges are major component of adult diets.

Economically, Odonata serves as important pest and beneficial insects. They serve as biocontrol agents for various plant pests and disease -spreading vectors such as mosquitoes [3] but can also attack beneficial insects such as bees [4]. They are also thought to cause losses among hatchling fishes in aquaculture facilities. They serve an important role in the ecological food chain by consuming aquatic larvae and being in turn consumed by birds and various amphibians. They are used as bioindicators for monitoring habitat degradation both on terrestrial and aquatic ecosystems because of their sensitivity to anthropogenic activities [5-7]. Dragonflies and Damselflies have a range of preference for different biotypes, from permanent shaded sites to temporary pools [8]. The choices of different biotopes by different species are used as a means of determining the extent to which landscapes have been affected [7]. The main causes of habitat loss include forest clearance, erosion, agrochemical runoff and deposition of domestic waste and sewage into water bodies [9].

Previous efforts have been made to document the distribution of Odonata in different biotypes in Nigeria. These studies include the works of Adu and Ogbogu at Aponmu forest [10], Adu et al at Iloyin forest Ondo State [11] and Kemabonta et al at the University of Lagos, Lagos State [12]. However, there are still existing gaps on the distribution of Odonata in South-South forest region of Nigeria. The objective of the present study was to determine the abundance and distribution of dragonflies in Akwa Ibom State, South-South Nigeria.

\subsection{MATERIALS AND METHODS}

Akwa Ibom is located along the coastal region on the southern part of the country called Niger Delta. It lies between latitudes $4^{\circ} 32^{\prime} \mathrm{N}$ and $5^{\circ} 33 \mathrm{~N}$, and longitudes $7^{\circ}$ $25^{\prime} \mathrm{E}$ and $8^{\circ} 25^{\prime} \mathrm{E}$. It has a total land area of $6187 \mathrm{~km}^{2}$ and is bordered on the south by the Atlantic Ocean [13]. The climate is tropical. Akwa Ibom records a mean annual rainfall of $3000 \mathrm{~mm}$ along the coast and this decreases northward towards the hinterland [14]. The vegetation pattern changes correspondingly, from mangrove swamp on the coast through the lowland rainforest towards the north. The topography is generally plain, although certain areas on its north-east end have undulating landforms with some places rising up to the height of $150 \mathrm{~m}$ above sea level. The State, which is largely rural in setting, records a high population of 3.9 million people [15], who are mainly subsistence farmers.

Study Site 1 is located at the banks of a large flowing river at the East of Akwa Ibom State, Ikot Akpaden is a heavily forested area (Latitude 5.0320 and Longitude 8.0721). Study Site 2 is located at Obio Akpa (Latitude 4.7924 and Longitude 7.6787 ) towards the western part of Akwa Ibom State. This site is a small pond with an open field and is in a small settlement surrounded by a small forest. Study Site 3 is Ikot Okoro ( Latitude 4.9800 and Longitude 7.7740) is located in the center of Akwa Ibom State. Individuals were collected from and around a pond bordered by small grassland and some trees. It is close to a major road in a large settlement. Study Site 4 is closely located towards the southern part of the state, Ikot Udofia (Latitude 4.8450 and Longitude 7.8451) is in a settlement. A small pond surrounded by buildings and an open field served as the collection point. Study Site 5 is Urua Udofia (Latitude 5.03370 and Longitude 7.9455) is on the eastern point of Akwa Ibom State. A small lake, with short trees around served as the study site. The site was a short distance from a large settlement. Study Site 6 is Obio Ndot (Latitude 4.6920 and Longitude 7.8930) is located towards the far southern region of Akwa Ibom State and is situated along a flowing river surrounded by a forested region a little distance from a small settlement (Figure 1).

\subsection{Sampling and Preservation of Adult Odonata}

Sampling was carried out between August and September, 2018. Samples were collected from each location from 7:00am to 6:0opm. For ease of identification, only adult dragonflies and damselflies were collected using a sweep net with $150 \mathrm{~cm}$ long handle and orifice $25 \mathrm{~cm}$ in diameter [16]. Collections were made in several microhabitats in each study site; on grasses, over the water, while perched on sticks and among the trees. Captured Odonates were placed in triangular envelops and were soaked in acetone for 12 hours and air dried. This allows the acetone to replace the liquid content in the insect and prevent microbial action [17]. The air dried insects were then identified and separated according to species type using standard identification manuals $[\mathbf{8 , 1 8}]$ They 
were also cross-referenced against over 2892 images of Afrotropical species of Odonata on the World Wide Web (www.africa-dragonfly.net/global/results) before being counted. Forty-seven unidentified individuals have been sequenced. The results will be presented elsewhere.

Figure 1: Map of Akwa Ibom State showing the study sites.

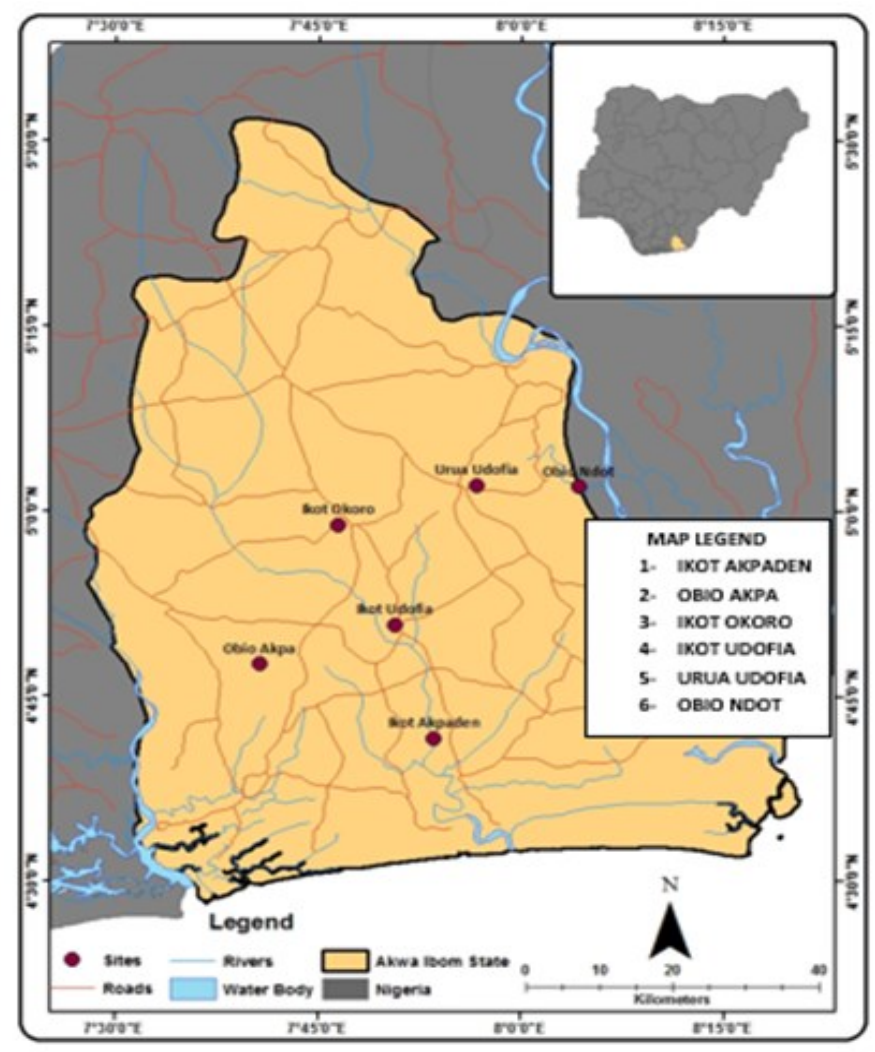

\subsection{Data Analysis}

Data collected were analyzed using relevant statistical packages (SPSS and PAST). The diversity indices used include Margalef index, Shannon Weiner diversity index, Simpson dominance index and Evenness index to determine species diversity. The diversity indices were used to determine the richness of the Odonata species at the different study sites. The higher the value of $\mathrm{H}^{\prime}$, the greater the diversity. Analysis of variance (ANOVA) was used to test for statistical differences between the study sites.

\subsection{RESULTS}

\subsection{Composition of Odonata in Akwa Ibom}

A total of 767 dragonflies and damselflies were recorded at the 6 study sites representing 24 species, 16 genera and 4 families (Libellulidae, Coenagrionidae, Calopterygidae and Chlorocyphidae) (Table 1).
Table 1: Distribution Pattern of Odonates in Akwa Ibom State

\begin{tabular}{|c|c|c|c|}
\hline Family & Genus & Scientific Name & Total \\
\hline \multirow[t]{19}{*}{ Libellulidae } & Orthetrum & Orthetrum chrysostigma & 56 \\
\hline & & Orthetrum stemmale & 6 \\
\hline & & Orthetrum austeni & 5 \\
\hline & & Orthetrum africanum & 1 \\
\hline & & Orthetrum julia & 25 \\
\hline & Acisoma & Acisoma panorpoides & 29 \\
\hline & & Acisoma trifidum & 9 \\
\hline & Thermochoria & $\begin{array}{l}\text { Thermochoria equivoca- } \\
\text { ta }\end{array}$ & 14 \\
\hline & Neodythemis & Neodythemis klingi & 18 \\
\hline & Palpopleura & Palpopleura Portia & 4 \\
\hline & & Palpopleura lucia & 314 \\
\hline & Tholymis & Tholymis tillarga & 1 \\
\hline & Hemistigma & Hemistigma albipunctum & 26 \\
\hline & Hadrothemis & Hadrothemis infesta & 8 \\
\hline & Chalcostephia & Chalcostephia flavifrons & 53 \\
\hline & Oxythemis & $\begin{array}{l}\text { Oxythemis phoenicosce- } \\
\text { les }\end{array}$ & 5 \\
\hline & Bradinopyga & Bradinopyga strachani & 3 \\
\hline & & Bradinopyga cornuta & 5 \\
\hline & Pantala & Pantala flavescens & 2 \\
\hline Calopterygidae & Phaon & Phaon iridipennis & 1 \\
\hline Chlorocyphidae & Chlorocypha & $\begin{array}{l}\text { Chlorocypha pyriformo- } \\
\text { sa }\end{array}$ & 3 \\
\hline \multirow[t]{3}{*}{ Coenagrionidae } & Ceriagrion & Ceriagrion glabrum & 94 \\
\hline & & Ceriagrion suave & 18 \\
\hline & Pseudagrion & Pseudagrion kersteni & 64 \\
\hline
\end{tabular}

Most of the species were from Libellulidae representing a total of $77 \%$ (Figure 2) while family Colopterygidae and Chlorocyphidae had the least number of species at less than 1\%. Papopleura lucia and Ceriagrion glabrum had the highest percentage total occurrence at $41 \%$ and $10 \%$ respectively (Figure 3). Amongst the families, Libellulidae had the highest abundance across the six sites followed by Coenagrionidae, with Chlorocyphidae and Calopterygidae having the lowest, respectively.

The composition of the species across the study sites is represented in Table 2. It shows that Ikot Udofia had the highest number of individuals collected at 238 (31\%) with Palpopleura lucia being the most abundant species (60\%). P. lucia was also the most abundant at Obio Ndot, Obio Akpa and Urua Udofia. On the other hand, Orthetrum chrysostigma and Asisoma trifidum were the most abundant specimens collected at Ikot Akpaden and Ikot Okoro respectively. P. lucia was the only common 


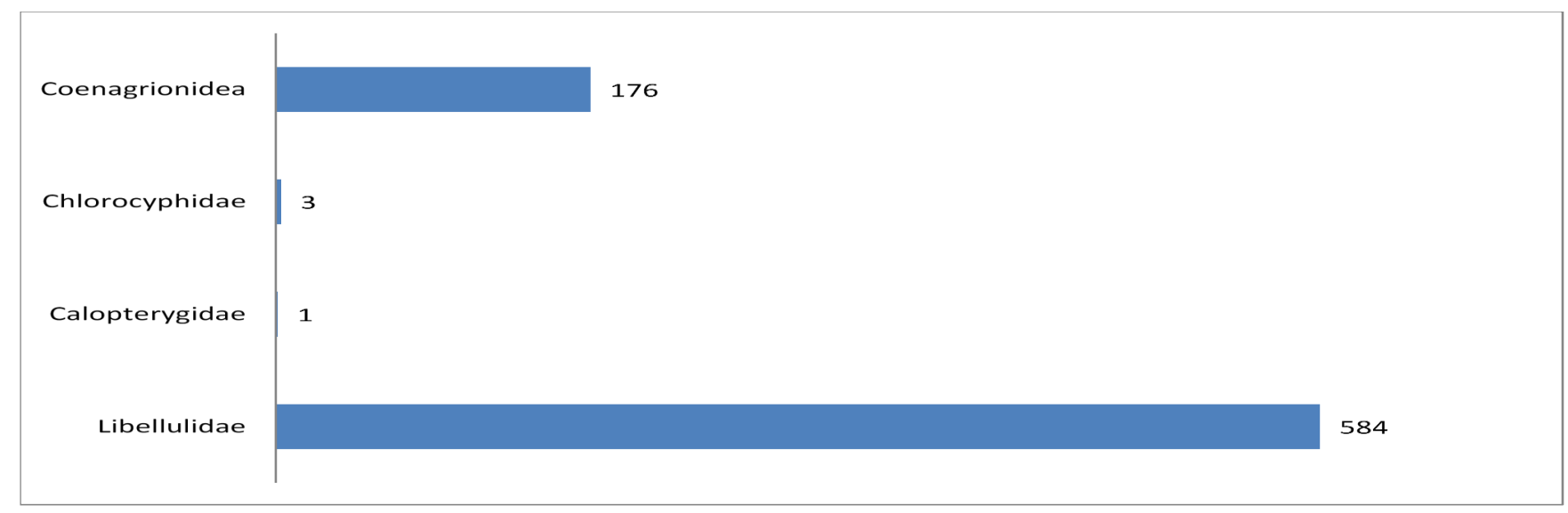

Figure 2: Number of individuals per families of Odonata collected in Akwa Ibom, Nigeria

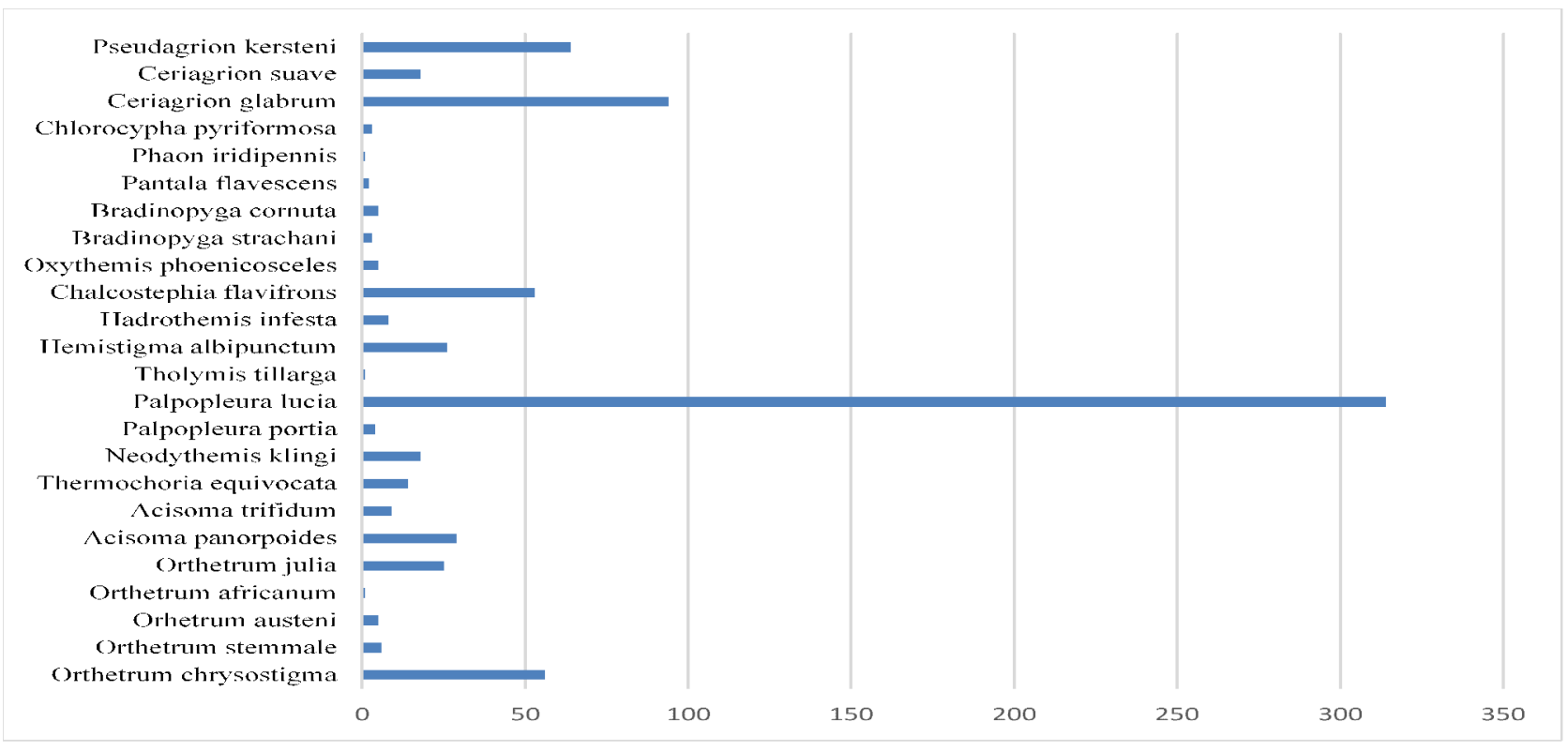

Figure 3 : Number of individuals of the different species collected

species found across all study sites. Chalcostephia flavifrons and Ceriagrion glabrum were the second most common species recorded, they were present in all the study sites except Ikot Okoro. The site with the highest and least number of species were Ikot Akpaden and Ikot Okoro respectively (Table 2)

\subsection{Diversity Indices}

Table 3 shows the diversity indices of Dragonflies and Damselflies at Akwa Ibom. Ikot Akpaden had the highest diversity $\left(H^{\prime}=2.39\right)$, followed by Obio Akpa $\left(H^{\prime}=1.81\right)$ and Urua Udofia was the least $\left(H^{\prime}=1.36\right)$. The study site that was most evenly distributed was Ikot Okoro $\left(\mathrm{e}^{\wedge} \mathrm{H} / \mathrm{S}=\right.$ $0.8028)$ and the least evenly distributed was Ikot Udofia $\left(\mathrm{e}^{\wedge} \mathrm{H} / \mathrm{S}=0.3292\right)$. Highest degree of species concentration was at Ikot Akpaden $(\mathrm{D}=0.8858)$ and Ikot Udofia had the least $(D=0.6117)$ concentration of species. There was no significant difference $(\mathrm{P}<0.05)$ in the mean number of odonata collected in the various sites

\subsection{DISCUSSION}

The high distribution of Libellulids recorded in the present study is in consonant with previous studies. Researchers have also reported wide representation of the species in many forests globally and locally $[12,19,20]$. Most of the libellulids sampled such as Palpopleura lucia, Orthetrum chrysostigma and Orthetrum julia are wi spread and tolerant of disturbed habitats.

This result is corroborated by Vick GS [17], who reported similar observation. Ceriagrion glabrum, Chalcostephia flavifrons and Palpopleura lucia were represented in all the sites. They can therefore be called generalists. Ceriagrion glabrum is widespread across West Africa [18]. It is known to prefer standing or sluggish water $[7,19]$. This could account for its abundance in the standing (ponds) or sluggish water bodies (4 sites) except in Ikot Akpaden and Obio Ndok that were flowing rivers. The abundance of Palpopleura lucia in this study agrees with the study of 
Adu et al[16] at Iloyin forest, Ondo state where it was found along with Palpopleura portia to have had the highest abundance of all libellulids.

Table 2: Distribution of Odonates across the sites.

\begin{tabular}{|c|c|c|c|c|c|c|}
\hline Odonates & IA & $\overline{O N}$ & IU & $\overline{\mathbf{O A}}$ & IO & $\overline{\mathrm{UU}}$ \\
\hline $\begin{array}{l}\text { Orthetrum } \\
\text { chrysostigma }\end{array}$ & 21 & 0 & 7 & 0 & 1 & 27 \\
\hline $\begin{array}{l}\text { Orthetrum } \\
\text { stemmale }\end{array}$ & 4 & o & o & o & o & 2 \\
\hline $\begin{array}{l}\text { Neodythemis } \\
\text { klingi }\end{array}$ & 12 & 1 & o & o & 5 & o \\
\hline $\begin{array}{l}\text { Palpopleura } \\
\text { lucia }\end{array}$ & 15 & 39 & 142 & 81 & 3 & 34 \\
\hline $\begin{array}{l}\text { Hadrothemis } \\
\text { infesta }\end{array}$ & 2 & $\mathrm{o}$ & 1 & 5 & o & $\mathrm{o}$ \\
\hline $\begin{array}{l}\text { Phaon } \\
\text { iridipennis }\end{array}$ & .1 & o & o & o & o & o \\
\hline $\begin{array}{l}\text { Orthetrum } \\
\text { austeni }\end{array}$ & 3 & o & 1 & o & o & 1 \\
\hline $\begin{array}{l}\text { Palpopleura } \\
\text { portia }\end{array}$ & 4 & o & o & o & o & o \\
\hline & 11 & 5 & 14 & 21 & o & 2 \\
\hline $\begin{array}{l}\text { Orthetrum } \\
\text { julia }\end{array}$ & 11 & o & 3 & o & o & 11 \\
\hline $\begin{array}{l}\text { Oxythemis } \\
\text { phoenicosceles }\end{array}$ & 5 & $\mathrm{o}$ & o & o & o & $\mathrm{O}$ \\
\hline $\begin{array}{l}\text { Chlorocypha } \\
\text { pyriformosa }\end{array}$ & 2 & o & o & o & 1 & o \\
\hline $\begin{array}{l}\text { Bradinopyga } \\
\text { cornuta }\end{array}$ & 5 & o & o & o & o & o \\
\hline $\begin{array}{l}\text { Bradinopyga } \\
\text { strachani }\end{array}$ & 3 & $\mathrm{o}$ & 0 & o & o & o \\
\hline $\begin{array}{l}\text { Ceriagrion } \\
\text { glabrum }\end{array}$ & 2 & 25 & 8 & 58 & o & 1 \\
\hline $\begin{array}{l}\text { Acisoma } \\
\text { panorpoides }\end{array}$ & 0 & 9 & o & 20 & 0 & 0 \\
\hline $\begin{array}{l}\text { Acisoma } \\
\text { trifidum }\end{array}$ & o & 1 & 2 & 0 & 6 & o \\
\hline $\begin{array}{l}\text { Pantala } \\
\text { flavescens }\end{array}$ & o & 1 & o & o & o & o \\
\hline $\begin{array}{l}\text { Hemistigma } \\
\text { albipunctum }\end{array}$ & o & 2 & 18 & 5 & o & 1 \\
\hline $\begin{array}{l}\text { Thermochoria } \\
\text { equivocate }\end{array}$ & o & 1 & 4 & 9 & o & o \\
\hline $\begin{array}{l}\text { Ceriagrion } \\
\text { suave }\end{array}$ & 0 & 5 & 3 & 10 & 0 & 0 \\
\hline $\begin{array}{l}\text { Pseudagrion } \\
\text { kersteni }\end{array}$ & 0 & 0 & 34 & 27 & 3 & $\mathrm{o}$ \\
\hline $\begin{array}{l}\text { Tholymis } \\
\text { tillarga }\end{array}$ & o & o & 1 & o & $\mathrm{o}$ & o \\
\hline $\begin{array}{l}\text { Orthetrum } \\
\text { africanum }\end{array}$ & o & $\mathrm{o}$ & o & o & 1 & o \\
\hline Total & 101 & 89 & 238 & 236 & 20 & 79 \\
\hline
\end{tabular}

Key: IA=Ikot Akpaden; ON=Obio Ndot; IU=Ikot Udofia; $\mathrm{OA}=$ Obio Akpa; $\mathrm{IO}=\mathrm{Ikot}$ Okoro; UU=Urua Udofia
Table 3: Diversity Indices of the Six Sites at Akwa Ibom State.

\begin{tabular}{lllllll}
\hline & IA & ON & IU & OA & IO & UU \\
\hline Taxa_S & 15 & 10 & 13 & 9 & 7 & 8 \\
Individuals & 101 & 89 & 238 & 236 & 20 & 79 \\
Shannon_H & 2.39 & 1.56 & 1.45 & 1.81 & 1.73 & 1.36 \\
Simpson_1-D & 0.89 & 0.71 & 0.61 & 0.79 & 0.80 & 0.66 \\
Margalef & 3.03 & 2.01 & 2.19 & 1.46 & 2.00 & 1.60 \\
Equitability_J & 0.88 & 0.68 & 0.57 & 0.82 & 0.89 & 0.65 \\
$\begin{array}{l}\text { Mean } \pm \text { Standa } \\
\text { rd error }\end{array}$ & $4.21 \pm$ & $3.71 \pm$ & $9.92 \pm$ & $9.8 \pm$ & $0.83 \pm$ & 3.29 \\
& $1.16^{\mathrm{a}}$ & $1.88^{\mathrm{a}}$ & $5.96^{\mathrm{a}}$ & $4.13^{\mathrm{a}}$ & $0.34^{\mathrm{a}}$ & \pm 1.78 \\
& & & & & & $\mathrm{a}$ \\
\hline
\end{tabular}

Key: IA=Ikot Akpaden; ON=Obio Ndot; IU=Ikot Udofia; $\mathrm{OA}=$ Obio Akpa; $\mathrm{IO}=\mathrm{Ik}$ ot Okoro; UU=Urua Udofia

The study site with largest number of individuals was Ikot Udofia with 238. Most of the study sites were located close to settlements with only one (Ikot Apaden) being a long distance from any settlement, though Ikot Apaden did not have the highest number of individuals, it had the highest species diversity of 16 species and Shannon (H') of 2.387 and Margalef's index of 3.034. The non-common species such as Oxythemis phoenicosceles and Chlorocypha pyriformosa were also found in Ikot Apaden river.

The lower numbers of species in other sites that are nearer to human settlements could possibly indicate that anthropogenic activities have caused some species to migrate from their habitats to more favorable locations. Most odonates found in the six sites have been reported $[7,16,17,18,19]$ especially in the forested areas of Nigeria except seven species that are reported in another write up.

In conclusion libellulidae is a family of species that have evolved the ability to thrive in areas that have come under anthropogenic influence and their large presence confirms it. It shows that species with narrow niches could not tolerate anthropogenic activities across the various sites. It is therefore imperative that proper forest management be embarked upon to prevent further loss of these species and loss of undiscovered rare and endemic species.

\section{Source of Funding}

This research received support from University of Lagos, Nigeria (CRC 2016/21) and GBIF (BID-AF2017-0311) grants 


\section{Declaration of Conflict of Interest}

The authors declare that there is no conflict of interest

\section{REFERENCES}

1. Heckman CW. Encyclopedia of South American Aquatic Insects: Odonata - Zygoptera. Springer, Olympia, Washington, USA. 2008; 694pp

2. Dijkstra KD. Demise and Rise: The Biogeography and Taxonomy of the Odonata of Tropical Africa. PhD Thesis, Lieden University. 2007; 143-187.

3. Kadarkarai M, Sanoopa CP, Pari M, Devakumar D, Jayapal S, Chellasamy P, et al. Rapid Biosynthesis of Silver Nanoparticles Using Crotalaria verrucosa Leaves Against the Dengue Vector Aedes aegypti: What Happens Around? An Analysis of Dragonfly Predatory Behaviour after Exposure at UltraLow Doses. Natural Product Research. 2016; 30(7): 826833.

4. Meyer J.. Odonata. https://projects.ncsu.edu/cals/course/ ent425/library/compendium/ odonata.html. 2016

5. Clausnitzer V. Teinobasis alluaudi From Mainland Africa: Notes on Ecology and Biogeography (Zygoptera: Coagrionidae). Odonatologica. 2003; 32: 321- 334.

6. Darwall W, Smith LT, Vie JC. The Status and Distribution of Freshwater Biodiversity in East Africa: Occasional paper of IUCN species survival. 2005; 31pp.

7. Samways MJ. Dragonflies and damselflies of South Africa. Pensoft Publishers, Moscow. 2008; 297pp.

8. Corbet PS. Dragonflies: Behaviour and Ecology of Odonata. Harley Books, Colchester, Essex, England. 2004; 829pp.

9. Primack R, Kobiri H, Mori S. Dragonflies Pond Restoration, Promotes Conservation Awareness in Japan. Biology. 2005; 14:1553-1554.

10. Adu BW, Ogbogu SS. Diversity and Community Structure of Dragonflies and Damselflies (Insecta: Odonata) in Aponmu
Forest South Western Nigeria. International Journal of Agriculture and Forestry. 2012; 3(6): 231-239

11. Adu BW, Ogbogu SS, Kemabonta KA. Dragonflies and Damselflies (Insecta: Odonata) as Tools for Habitat Quality Assessment and Monitoring. FUTA Journal of Research in Sciences. 2015b; 1: 36-45.

12. Kemabonta KA, Adu BW, Ohadiwe AC. Impact of Human Disturbance on the Abundance, Diversity and Distribution of Odonata in The University of Lagos, Akoka, Lagos, Nigeria. The School of Agriculture and Agricultural Technology, The Federal University of Technology, Akure. 2016; 21(3): 143-150.

13. Jacob A, Peter U. Dimensions in Rural Water Coverage and Access in Akwa Ibom State, Nigeria. African Journal of Environmental Science and Technology. 2015; 9(1): 29-37.

14. Akpan-Ebe IN. Gap-Phase Dynamics and Natural Regeneration in the Stubbs Creek Forest Reserve of Akwa Ibom State, Nigeria. Ph.D Thesis, University of Ibadan. 2005; 221pp.

15. Polhemus DA, Asquith A. Hawaiian Damselflies: A Field Identification Guide. Bishop Museum Press, Honolulu, HA. 1996; 122pp.

16. Adu BW, Akindele EO, Obadofin AA. Composition and Distribution of Dragonflies and Damselflies (insect: Odonata) in Iloyin forest, Akure, Southwestern Nigeria. Ethiopian Journal of Environmental Studies and Management. 2015a; 8(5): 517-529.

17. Vick GS. Biodiversity Assessment of the Odonate Fauna of the Takamanda Forest Reserve, Cameroon. 2003; 8(1): 7382.

18. Dijkstra KD, Monaghan MT, Pauls SU. Freshwater Biodiversity and Aquatic Insect Diversification. Ann Rev Entmol. 2014; 59: 143-63.

19. Che-Salmah MR. Studies of Aquatic Insects, with Emphasis on Dragonflies (Insecta: Odonata) as a Tool in Biomonitoring of Freshwater Ecosystem. The School of Biological Sciences, University Sains, Malaysia. 2001; 200pp. 